\title{
TRTakademi
}

ISSN 2149-9446 | Cilt 07 | Sayı 14 | Ocak 2022 | Sosyal Medya

\section{Aşı Kararsızlığı Bağlamında Aşı Tartışmaları: Twitter'da Kovid-19 Örneği}

\author{
Didem NARMANLI*
}

\begin{abstract}
Öz
Kovid-19 aşılarının geliştirilerek uygulanmaya başlanmasıyla birlikte ülkeler pandemiyle mücadelede aşılama programlarına başlamışlardır. Aşıya erişimde herhangi bir sıkınt yaşanmamasına rağmen veriler, Türkiye'de aşılama oranlarının pandemiyle mücadelede istenen düzeyde olmadığını göstermektedir. Aşı kararsızlığı ve infodemi arasındaki ilişkinin sorunsallaştırıldığı bu çalışmanın amacı Twitter'da aşı ile ilgili tartışmaların ne olduğunu belirleyerek aşı kararsızlığı yaşayan kullanıcıların argümanlarını infodemi bağlamında değerlendirmektir. Bu bağlamda araştırmada Twitter'da aşı ile ilgili hangi konuların tartışıldığı, aşıya karşı güvensizliğin nedeni olarak neler ifade edildiği, aşı kararsızlığı yaşayan kullanıcıların tweetlerinde hangi yanlış bilgilerin öne çıktı̆ı ve aşı kararsızlığı yaşayan kullanıcıların argümanlarına dayanak olan komplo teorilerinin hangileri olduğu sorularına yanıt aranmıştır. Çalışmada 2349 tweete nicel içerik çözümlemesi ve betimsel çözümleme uygulanmıştır. Çalışmada aşı kararsızlığı yaşayan kullanıcıların aşı tutumlarının homojen olmadığı, aşı ile ilgili tartışmaların çoğunlukla kullanıııların bazı hak ve hizmetlerden yararlanabilmek için aşı ve PCR testi yaptırmak zorunda kalmalarından kaynaklandığı, küresel ilaç şirketlerine ve sağlık sisteminin aktörlerine güvenmedikleri ve aşı ile ilgili argümanlarını sıklıkla komplo teorilerine, aşının yan etkilerine, aşının virüse karşı herhangi bir koruyuculuğu olmadığına ve aşının faz çalışmalarını tamamlamadığına dair yanlış bilgiye dayandırdıkları bulunmuştur.
\end{abstract}

Anahtar Kelimeler: Infodemi, Yanlış Bilgi, Twitter, Aşı Kararsızlığı, Komplo Teorileri

*Dr. Öğr. Üyesi, Süleyman Demirel Üniversitesi Illetişim Fakültesi Radyo, Televizyon ve Sinema Bölümü, didemcabuk@sdu.edu.tr

Narmanlı, D. (2022). Aşı Kararsızlığı Bağlamında Aşı Tartışmaları: Twitter'da Kovid-19 Örneği. TRT Akademi, 7 (14), 28-57. DOI: 10.37679/trta.1013435

\section{Araştırma Makalesi}

Geliş Tarihi: 22.10.2021

Revizyon Tarihi: 22.12.2021

Kabul Tarihi: 14.01.2022

ORCID ID: 0000-0002-0337-1312 DOI: 10.37679/trta.1013435 


\title{
TRTaKadeмi
}

ISSN 2149-9446 | Volume 07 | Issue 14 | January 2022 | Social Media

\section{Vaccine Debates in the Context of Vaccine Hesistancy: Covid 19 Case on Twitter}

\author{
Didem NARMANLI
}

\begin{abstract}
With the development and implementation of Covid 19 vaccines, countries have started vaccination programs to combat the pandemic. Although there is no barrier in accessing the vaccine, the data show that the vaccination rates in Turkey are not at the desired level in the fight against the pandemic. The aim of this study, in which the relationship between vaccine hesitancy and infodemic is problematized, is to identify the debates about Covid 19 vaccines and to evaluate the arguments of the vaccine hesitant users in the context of the infodemic. In this context, the research sought answers to the questions of which vaccinerelated topics are discussed on Twitter, what is expressed as the cause of vaccine mistrust, what false information is prominent in the tweets of users who are hesistant about vaccines, and which conspiracy theories are the basis for the arguments of users who are hesistant about vaccines. Quantitative content analysis and descriptive analysis were applied to 2349 tweets in this study. In the study, it was found that the vaccine attitudes of users with vaccine hesistancy are not homogeneous, the discussions about the vaccine mostly stemmed from the fact that the users had to have a vaccine and PCR test in order to benefit from some rights and services, users do not trust global pharmaceutical companies and actors of the health system. They also based their arguments about the vaccine mostly on conspiracy theories and the disinformation about the side effects of the vaccine, the fact that the vaccine has no protection against the virus, and the vaccine has not completed phase studies.
\end{abstract}

Keywords: Infodemic, Disinformation, Twitter, Vaccine Hesitancy, Conspiracy Theories 


\section{Giriş}

Kovid-19 pandemisiyle birlikte virüsün yol açthğı hastalığın tedavisine ilişkin çalışmalar da başlamış; pandeminin ilk zamanlarında mevcut olan bazı ilaçların tedavi amaçı kullanılmasının ardından aşı çalışmaları hız kazanmıştı. Çin, Almanya, Rusya ve Amerika Birleşik Devletleri gibi ülkelerde farklı ilaç şirketleri tarafindan virüse karşı farklı aşılar geliştirilmiştir. Aşıların geliştirilmesinden ve kullanımına onay verilmesinden kısa bir süre sonra Türkiye'de de kovid-19 pandemisiyle mücadelede aşılama çalışmaları kademeli olarak başlamıştır.

Pandemi sürecinde karşı karşıya kaldığımız yalnızca küresel bir sağlık krizi değil, aynı zamanda sosyal medyada dolaşan yanlış bilgi krizidir. Sosyal medyanın eskisinden çok daha fazla sayıda enformasyonun dolaşıma girmesine ve bireylerin bu enformasyona daha hızlı erişebilmesine olanak sağlaması sıkıkla bir avantaj olarak değerlendirilse de enformasyon üzerindeki düşünme, denetleme ve teyit etme olanağımız kısıtlanmıştır. Demokrasi ve toplumsal kutuplaşma bağlamında uzun zamandır tartışılmakla birlikte yanlış bilgi, pandemi sürecinde insanların hastalığa karşı alınan önlem ve tedbirlere uymasına engel teşkil ettiği için ilk kez bir kamu sağlığı meselesi olarak karşımıza çıkmıştr.

Yanlış bilginin kamu sağlığı açısından teşkil ettiği soruna dikkat çeken Dünya Sağlık Örgütünün (DSÖ) literatüre kazandırdığı infodemi kavramı, bazıları doğru ama bazıları yanlış olan bilgi yığınını ve bu yığın karşısında insanların doğru bilgiye ulaşmasının zorluğunu ifade etmektedir. Literatürde yer alan çok sayıda çalışma, infodeminin pandemi sürecindeki zararlarını ortaya koymaktadır (bkz. PAHO, 2021; Yıldırım, 2020; Brennan vd., 2020, Gölbaşı ve Metintaş, 2020; BiLGimag, 2020). Bu çalışmalarda sosyal medyada pandemiyle ilgili dolaşıma giren komplo teorileri, dezenformasyon ve mezenformasyon gibi yanlış bilgi türleri tanımlanmış; bunların kamunun hastalıkla ilişkili güvenilir ve doğru bilgiye ulaşarak gerekli sağlık tedbirlerini almasını zorlaştırdığı belirtilmiştir.

Pandemi sürecinde kovid-19 aşılarının geliştirilerek kullanılmaya başlanmasıyla birlikte yaşamın normalleşebilmesi için DSÖ, aşıların önemine dikkat çekerken (DSÖ, 2021a) ülkeler toplumsal bağışıklığın oluşabilmesi için hedefledikleri aşılama oranlarına ulaşmakta zorluk yaşamaktadır. Aşı kararsızlığı, aşıya erişimin mümkün olduğu ülkelerde hedeflenen aşılama oranlarına ulaşılabilmesinin önündeki en büyük engeldir. Aşı karşııt gruplar; kampanyalar, yayınlar ve internet siteleri aracılığıyla insanların aşılar hakkındaki risk algısını ve dolayısıyla aşılama oranlarını etkilemektedir (DSÖ, 2017, s. 19). Bu nedenle aşıyla ilgili kaygıların ve bu kaygıların nedenlerinin anlaşılması, aşılamanın başarısı açısından oldukça önemlidir (Yıldız, vd., 2021). 
DSÖ (2013) aşı kararsızlığını etkileyen faktörlerden birinin iletişim ve medya araçları olduğunu belirtmiştir. Nitekim kovid-19 aşılarının geliştirilmesi ve uygulanmaya başlanmasıyla birlikte aşılarla ilgili birçok komplo teorisi ve yanlış bilgi de sosyal medyada dolaşıma girmiştir. Bu nedenle bu çalışmada aşı kararsızlığı ve infodemi arasındaki ilişki sorunsallaştırılarak Twitter'da aşı kararsızlığı yaşayan kullanıcıların argümanlarının infodemi bağlamında değerlendirilmesi amaçlanmıştır. Bu amaçla çalışmada öncelikle literatür temelinde infodemi ve yanlış bilgi kavramları, ardından aşı kararsızlığı tanımlanarak irdelenmiştir. Çalışmada Twitter'da aşı ile ilgili hangi konuların tartışıldığı, aşıya karşı güvensizliğin nedeni olarak neler ifade edildiği, aşı kararsızlığı yaşayan kullanıcıların tweetlerinde hangi yanlış bilgilerin öne çıktığı ve aşı kararsızlığı yaşayan kullanıcıların argümanlarına dayanak olan komplo teorilerinin hangileri olduğu sorularına yanıt aranan araştirma bölümünde ise aşı kararsızığı yaşayan kullanıcıların atmış olduğu 2349 tweet nicel ve nitel olarak çözümlenerek aşı kararsızlığının infodemi ile ilişkisi tartışımıştır.

\section{Aşı Kararsızıı̆ı}

Aşı, virüs kaynaklı hastalıkları ifade eden enfeksiyon hastalıklarıyla mücadelede hâlâ daha en etkili korunma yöntemidir. Bulaşıcı salgın hastalıkların önlenmesi ve kontrolü için kritik bir öneme sahip olan aşılar, insanların bağışıklık sisteminin virüsle kontrollü bir şekilde tanışmasını ve güçlenmesini sağlayarak küresel sağlık güvenliğinin sağlanmasında hayati bir araçtır (DSÖ, 2021b). Gelişmiş ülkelerde bazı enfeksiyon hastalıklarının azalması, çocuk felci gibi bazı enfeksiyon hastalıklarının belirli coğrafyalardan silinmesi ve çiçek hastalığı gibi bazı enfeksiyon hastalıklarının ise tüm dünyada ortadan kaldırılması aşılarla mümkün olmuştur (Badur, 2011).

Kovid-19 pandemisiyle birlikte gündelik yaşamımızda sıklıkla duymaya başladığımız aşı karşıtığının tarihi ilk aşı çalışmasının yapıldığı 1796 yılına uzanmaktadır. Edward Jenner'ın sığır çiçeği hastalığına karşı aşı çalışmaları bir din bilgini olan E. Massey tarafindan tanrıya karşı gelerek şeytana uymak olarak değerlendirilmiştir (Kader, 2019, s. 378). Bununla birlikte 1850'lerde İngiltere'de ilk aşı karşıt hareketlerin şekillenmesinden beri aşıların güvenli veya etkili olmadığını ve ayrıca aşılamanın dini inançlarla veya insan haklarıyla bağdaşmadığını savunan çeşitli gruplar var olmuştur. 1970'lerde ve 1980'lerde küresel ölçekli aşı karşıtı lobicilik faaliyetleri bazı ülkelerde boğmaca aşısının durdurulmasına neden olmuştur. 1990'ların sonuna kadar bu ülkelerdeki boğmaca vakalarının sayısı aşılamaya devam eden ülkelere nazaran 10 ila 100 kat artmıştır (DSÖ, 2017, s. 19). 
Aşı karşıtlığı tüm aşıların reddedilmesini ifade eden kutuplaştırıcı bir terimdir. Aşılara karşı en eleştirel olan insanlar bile kendilerinin aşı karşıtı olarak tanımlanmasına itiraz etmektedir. Nitekim çağrıştırdığı olumsuz anlamlar göz önünde bulundurulduğunda insanları aşı karşıtı olarak etiketlemek onların aşı kabulünü sağlamasını olumsuz etkilemektedir. Buna karşın literatürde önerilen aşı kararsızığı terimi, tartışmayı karşıtlık veya savunuculuk şeklindeki dikotomik bir bakış açısından uzaklaştırmakta; aşı davranışını aktif talepten tüm aşıların tamamen reddedilmesine kadar uzanan bir dizi potansiyel tutum ve davranış olanağı üzerinden tanımlayan bir yaklaşım değişimini ifade etmektedir (Dubé vd., 2021, s. 177-178). Aşı konusunda kararsızlık yaşayan bireyler, belirli aşılar veya genel olarak aşılama konusunda değişen derecelerde kararsızlıkları olan heterojen bir gruptur. Bazıları, aşılar hakkındaki endişeleri sürse de tüm aşıları kabul edebilir; bazıları, bazı aşıları kabul ederken diğerlerini reddedebilir veya geciktirebilir, bazıları ise tüm aşıları reddedebilirler (DSÖ, 2013 s.1). Yani aşı kararsızlığı aşıyla ilgili şüpheleri ve kaygıları ortak olmakla birlikte aşı davranışı çeşitlilik gösteren bireyleri anlatmak için kullanılan bir terimdir.

Aşı kararsızlığı güven (aşıya veya sağlayıcıya güvenme), hâlinden memnun olma (aşı ihtiyacını algılamama, aşıya değer vermeme) ve uygunluk (erişim, zaman) gibi bir dizi faktörden etkilenen bir davranıştır (DSÖ, 2013, s. 1). Bununla birlikte daha önceki salgın enfeksiyon hastalıklarına yönelik çalışmalar aşıların kabulünü etkileyen iki ana neden ortaya koymaktadır. Bunlardan ilki olan yapısal engeller, bireylerin aşıya ve aşı hizmetlerine erişimini engelleyen konuları ifade etmektedir. İkinci neden olan tutumsal engeller ise bireylerin aşı hizmetlerini arama veya kabul etme isteğini azaltan inançlar veya algılardır. Hastalığın önlendiğine dair gönül rahatlığı, aşıların zararlarına dair risk algısı; aşılara, aşıyı üreten, denetleyen ve dağıtan kurumlara ve sağlık çalışanlarına duyulan güvensizlik; aşılar hakkında korku ve belirsizlik yaratmayı amaçlayan yanlış bilgi; aşılar ve aşılama önerileri hakkındaki bilgi eksikliğinden kaynaklanan yanlış kanılar, tutumsal engellerdir (Fisk, 2021, s. 52). Nitekim Downs, De Bruin ve Fischhoff (2008'den aktaran Etesaminia ve Bağcı Derinpınar, 2021, s. 384) çocukluk aşılarını reddeden veya erteleyen ebeveynlerin aşılarla ilgili bilgi almak için interneti kullanma olasılıklarının çocukluk aşılarını tam olarak yaptıran ebeveynlerden daha yüksek olduğunu bulmuştur.

Atalay (2019) günümüzdeki aşı kararsızıı̆ını sağlıkta modern paradigmadan postmodern paradigmaya geçişle açıklamaktadır. Buna göre; bir yandan gerçeğin ne olduğunun önemini yitirdiği hakikat sonrası durumla komplo teorileri güç kazanırken diğer yandan olgu ve fikir arasındaki sınır silikleşmiş ve fikirler olgular kar- 
Şısında yükselmiştir. Olgusal olanın merkezi bir yere sahip olduğu modern durumdan postmodern duruma geçişte bireysel fikirler, hikâyeler, duygular ve değerler önem kazanmaktadır. Bununla birlikte deregülasyon politikalarıya devletin sağlık alanından çekilmesi ve sağı̆̆ın ticarileşmesi küresel çapta faaliyet gösteren ilaç şirketlerinin kâr amaçlı faaliyetlerine yönelik şüphelerin ortaya çıkmasına neden olmuştur. Neoliberal sağlık politikaları, öne çıkardığı bireysel seçim vurgusuyla, bireyleri sağlık seçimleri konusunda birincil yetkili konuma getirerek daha fazla sorumluluk almaya çağırmaktadır. Bu minvalde sağlık, bireylerin seçim yaptıkları bir tüketim nesnesine dönüşerek medyada bir gösteri hâlini almaktadır.

Özceylan, vd.'ne göre (2020, s. 1038) gelişmekte olan ülkelerde aşı kararsızlığı nedenleri gelişmiş ülkelerdekinden farklılaşmaktadır. Buna göre Türkiye'de aşı kararsızlığının en önemli iki nedeni, aşıları üreten şirketlere duyulan güvensizlik ve sosyal medya başta olmak üzere medya ve internette aşının zararlı olduğuna dair yer alan bilgilerdir. Akyüz (2021) ise kendisini muhafazakâr/dindar ve milliyetçi olarak tanımlayan kişilerin aşı yaptırma tutumunun daha düşük olduğunu; kendisini laik olarak tanımlayan kişilerin ise hükûmetin vaka sayılarını gizlediğine yönelik daha yüksek tutuma sahip olduğunu bulmuştur. Buna göre muhafazakâr/ dindar kesimin aşı kararsızlığında Batı'ya duyulan güvensizlik, dünyayı güçlü ailelerin ve merkezlerin yönettiği ve bedenin kutsallığı inancıyla kürtaj gibi bazı müdahaleleri reddetme davranışları etkilidir.

\section{3. İnfodemi ve Kovid-19 Aşılarıyla İlgili Yanlış Bilgiler}

İnfodemi, internet teknolojilerindeki gelişmeyle birlikte doğru bilgi kadar yanlış bilginin de bir yığın hâlinde dolaşıma girmesini ve bu yığın içerisinde bireylerin ihtiyaç duyduğu doğru ve güvenilir bilgiye erişme zorluğunu ifade etmektedir (DSÖ, 2020). Bu nedenle infodemi, insanların doğru ve yanlış bilgiyi ayırt edebilmesi önündeki en büyük sorunlardan birisidir. MacDonald ve Dubé (2020), sosyal medyada aşılarla ilgili dolaşımda olan çok sayıdaki yanlış bilginin insanların bilimsel bilgileri görmesini engelleyerek aşılarla ilgili tutumlarını büyük ölçüde etkilediğini belirtmiştir. Benzer şekilde Brennan vd., (2020) kovid-19 ile ilgili yanlış bilgi ve komplo teorilerinin en çok çevrim içi yayıldığını ortaya koymuştur.

Yanlış bilgi her zaman kamusal bir mesele olmuştur. Bununla birlikte infodemi kavramı bu eski meselede yeni olanın yanlış bilginin üretim ve dolaşım hızı olduğunun altını çizer. Geleneksel medyaya kıyasla kullanıcı türevli içeriklere izin veren sosyal medya daha demokratik bir mecra olarak kabul edilse de paylaşılan içeriğin doğruluğu üzerinde denetim sağlamak ve yanlış bilginin yol açtı̆̆ zararlara yönelik bir yaptırım uygulamak oldukça güçtür. Bu kapsamda YouTube, 
Facebook, Instagram ve Twitter, infodemiyle mücadele etmede kendi denetim mekanizmalarını oluşturmaya başlamıştır (YouTube, 2021; Facebook; 2021; Twitter, 2021). Bununla birlikte internette dolaşıma giren yanlış bilgiyle mücadele eden doğrulama platformlarının sayısı ve önemi de giderek artmaktadır. Türkiye'de ilk doğrulama platformu olan YalanSavar.org faaliyetlerine 2009 yılında sosyal medyada dolaşıma giren domuz gribi ile ilgili paylaşımların doğruluğunu inceleyerek başlamıştır. Türkiye'de şu anda faaliyet gösteren sekiz doğrulama platformu vardır. Bunlar YalanSavar.org, Malumatfurus.org, EvrimAgaci.org, DogrulukPayi.com, Teyit.org, gununyalanlari. com, FactCheck.TR ve Doğrula.org'dur. (Ünver, 2020).

Doğrulama platformları, internet ortamında dolaşıma giren bilgilerin doğrulanması dışında belirli konularda hazırladıkları dosyalarla yanlış bilgiyle mücadelede önemli roller üstlenmektedir. Teyit.org, Türkiye'de aşı karşıtığını anlayabilmek için Twitter'da aşılarla ilgili kasten yanlış bilgi yayan hesapları incelemiş ve aşılarla ilgili yanlış bilgi yayan tweetlerin etkileşim oranlarının 2020 yılına kıyasla yaklaşık üç kat arttı̆ını bulmuştur. Bununla birlikte araştırmada incelenen 36 hesap tarafindan atılan tweetlerde karşılaşılan aşı karşıtı anlatıların 5 başlık altında toplandığı belirlenmiştir (Teyit.org, 2021d):

1. mRNA Merkezli Anlatılar: mRNA aşılarının Bill Gates, Uğur Şahin ve diğer küreselcilerin bir oyunu olduğundan söz eden anlatilar.

2. Bill Gates ve "küreselciler" merkezli anlatılar: "biyoterörist" ve "küresel çete" gibi kelimelerin sıklıkla kullanıldığı bu anlatıda bazen Bill Gates'in insanlara komut vermek ve onları kullanabilmek için Sinovac, Moderna ve BioNTech aşılarına çip yerleştirdiği, bunun için de CDC ve DSÖ gibi kurumlarla veya Uğur Şahin'le beraber çalıştğı öne sürülmektedir. Bazı tweetlerde ise illüminati ve Rockefeller isimleri de geçmektedir.

3. Yan etki merkezli anlatılar: Aşıların psikolojik bunalım, miyokardit, alerji, anaflaktik şok, parkinson, alzheimer ve çocuklarda otizme yol açması gibi yan etkileri olduğunun vurgulandığı bu tweetlerde aşının ölümleri engellemediği ve aşılardan sonra ölüm oranlarının daha çok arttğı iddia edilmektedir.

4. Hak merkezli anlatılar: Bu anlatıda aşı zorunluluğunun bireysel hakları ihlal ettiği ve aşı pasaportu uygulamasıyla asıl amaçlananın insanları takip ederek hareketlerinin kontrol altına alınması olduğu iddia edilmektedir.

5. Yeni varyant merkezli anlatılar: Delta varyantının ortaya çıkışının da kovid-19'daki gibi bir aldatmaca olduğu fikrine dayanan bu anlatıda aşıların yeni varyantlara karşı etkili olmadığı iddia edilmektedir. 
DogrulukPayi.com (2021a) da yine hazırladığı bir bültende kovid-19 aşısı ile ilgili yaygın olarak paylaşılan yanlış bilgileri derlemiştir. Buna göre Astrazeneca/Oxford kovid-19 aşısının DNA'yı değiştirmek amacıyla üretildiği, Uğur Şahin'in kovid-19 aşısı olmadığı, Pfizer-BioNTech aşısı çalışmalarında 6 kişinin öldüğü, kovid-19 aşılarının iç organlara zarar verdiği, Bill Gates'in aşılarla nüfusu azaltmak istediği, Pfizer-BioNTech aşı çalışmalarında dört gönüllünün geçici yüz felci geçirdiği, Türkiye'ye gelecek olan kovid-19 aşılarının içeriğinde fetüs olduğu, aşı ve ilaçların hastalık üreterek bağışıklık sistemini çökerttiği, İngiltere'de kovid-19 aşısı olduktan sonra düşük yapan kadınların sayısının \%366 arttı̆ı iddiaları en sık paylaşılan yanlış bilgilerdir.

\section{Yöntem}

Çalışmanın amacı infodemi bağlamında Twitter'da kovid-19 aşılarıyla ilgili tartışmalarda aşı kararsızlığına etki eden faktörlerin belirlenmesidir. Bu amaç doğrultusunda araştırmada şu sorulara yanıt aranmıştır:

1. Twitter'da aşı ile ilgili hangi konular tartışılmaktadır?

2. Twitter'da aşıya karşı güvensizliğin nedeni olarak neler ifade edilmiştir?

3. Twitter'da aşı kararsızlığı yaşayan kullanıcıların tweetlerinde hangi yanlış bilgiler öne çıkmaktadır?

4. Twitter'da aşı kararsızlığı yaşayan kullanıcıların argümanlarına dayanak olan komplo teorileri hangileridir?

Araştırmanın evrenini Twitter'da kovid-19 aşılarıyla ilgili olarak atılan olumsuz tweetler oluşturmaktadır. Evrene ilişkin bir bilgi olmaması nedeniyle örneklemin belirlenmesinde hashtag'lerden yararlanılmış ve olasılıklı olmayan örnekleme tekniklerinden biri olan kartopu örnekleme tekniği kullanılmışttr. Buna göre ilk adım olarak 20 Eylül-29 Eylül 2021 tarihleri arasında \#aşı hashtagiyle atılan tweetler Twitonomy uygulamasıyla indirilmiştir. Ardından bu hashtage eşlik eden ve aşıyla ilgili olumsuz tutum belirten diğer hashtagler belirlenerek o hashtaglerle aynı tarih aralığında atılan tweetler indirilmiştir. Bu hashtagler ve tweet sayıları Tablo 1.'de gösterilmiştir. 
Tablo 1. Örneklemin Belirlenmesinde Kullanılan Hashtagler

\begin{tabular}{|l|r|}
\hline \# Hashtag & Tweet Sayısı \\
\hline \#asıvepcrdurdurulsun & 6131 \\
\hline \#asıdeğilbiyolojiksilah & 3908 \\
\hline \#asımağdurları & 3304 \\
\hline \#aşı & 3077 \\
\hline \#asımasıolmıycam & 3004 \\
\hline \#aşıhakkında & 2573 \\
\hline \#asıdapcrdaolmuyoruz & 955 \\
\hline \#asilananlarasiyianlatiyor & 882 \\
\hline \#asiyahayır & 683 \\
\hline \#aşızulmü & 346 \\
\hline \#asızorbalığınadiren & 312 \\
\hline
\end{tabular}

Toplanan tweetlerden birbirinin aynısı olan, retweet olan, yalnızca hashtaglerden oluşan, aşıyla ilgili olumlu tutum ifade eden, aşıyla ilgili olmayan ve yabancı dilde olan tweetler ile haber tweetleri elendikten sonra 2349 tweet örneklemi oluşturmuştur.

Verilere nicel içerik çözümlemesi ve betimsel çözümleme uygulanmıştır. İçerik çözümlemesi elde edilen verileri özetlemek için kullanılan bir çözümleme tekniğidir (White ve Marsh 2006, s. 30-31). Nicel içerik çözümlemesinde veriler daha önceden oluşturulan ve tanımlanan kategoriler altında kodlanır. Böylelikle veriler sıkıştırılarak sistematik hâle getirilir (Stemler, 2000). Nicel içerik çözümlemesinde kullanılan kodlama cetveli, tweetlerin konuları ve içerikleri göz önünde bulundurularak araştırmacı tarafindan oluşturulmuştur. Kodlama iki farklı araştırmacı tarafindan bir tweet yalnızca bir kategoriye dahil edilecek şekilde yapılmıştır. Tweetin birden fazla kategoriyle ilgili olması durumunda tweetin öncelikli vurgusu, kullandığı hashtagler ve varsa ekli olan resim ve videolar da dikkate alınarak öncelikli kategoriye dâhil edilmiştir. Nicel içerik çözümlemesinde Krippendorff alfa $(\alpha)$ güvenilirlik değeri 0.85 olarak hesaplanmıştır. Veriler PASW Statistics 18 paket programıyla çözümlenmiştir. Twitter'da aşı tartışmalarını ve kullanıcıların aşıyla ilgili argümanlarını daha derin ele alabilmek amacıyla betimsel çözümlemeden yararlanılmıştır. Verilerin doğrudan alıntılarla tanımsal bir yaklaşım hâlinde sunulduğu betimsel çözümleme (Wolcott, 1994) verilerin çalışmanın amacına uygun olarak önceden belirlenen bir çerçeveden hareketle belirli temalar altında özetlenmesi ve yorumlanmasına dayanan bir tekniktir (Altunışık, vd., 2010). 


\section{Bulgular}

\subsection{Nicel İçerik Çözümlemesi Bulguları}

Aşı ile ilgili olumsuz tutum gösteren tweetler konularına göre 13 ana kategori altında ayrışmaktadır. Bu kategoriler Tablo 2'de gösterilmiştir.

Tablo 2. Konularına Göre Tweetler

\begin{tabular}{|l|r|r|}
\hline \multicolumn{1}{|c|}{ Ana Kategoriler } & \multicolumn{1}{c|}{ Tweet Sayısı } & \multicolumn{1}{c|}{ Yüzde } \\
\hline A. Aktörler, kurumlar ve uygulamalar & 833 & $\% 35,4$ \\
\hline B. Aşı güvenilirliği & 724 & $\% 30,8$ \\
\hline C. Hak temelli itiraz & 258 & $\% 11$ \\
\hline E. Aşı olmayacağım & 152 & $\% 6,5$ \\
\hline D. Desteklenenler & 111 & $\% 4,7$ \\
\hline F. Sorular & 61 & $\% 2,6$ \\
\hline G. Ülkelerden örnekler & 44 & $\% 1,9$ \\
\hline H. Uygulamada tutarsızlık & 43 & $\% 1,8$ \\
\hline I. Alıntılar & 37 & $\% 1,6$ \\
\hline I. Enformasyon paylaşma & 33 & $\% 1,4$ \\
\hline J. Şifa ve baş sağlığı dilekleri & 22 & $\% 1$ \\
\hline K. Aşı taraftarları/aşı olanlar & 19 & $\% 0,8$ \\
\hline L. Ayrımcılık/ötekileştirme & 12 & $\% 0,5$ \\
\hline Toplam tweet sayısı & 2349 & $\% 100$ \\
\hline
\end{tabular}

Aşıyla ilgili tweetlerin yaklaşık \%35,4'ünü pandemi sürecinde rol alan aktörler, kurumlar ve uygulamalarla ilgili itiraz ve eleştiri tweetleri; yaklaşık \%30'unu ise kovid-19 aşılarının güvenilirliğini konu edinen tweetler oluşturmaktadır. Bunları sırasıyla aşı uygulamalarına ve politikalarına ilişkin hak temelli itirazları kapsayan tweetler (\%11), kullanıcıların herhangi bir argüman veya gerekçe öne sürmeksizin aşı olmayacaklarını ve uygulamalara karşı direneceklerini ifade ettikleri tweetler $(\% 6,5)$; konuşmaları ve eylemleriyle aşıya mesafeli konumlanan kullanıcıların destekledikleri kişilerle ilgili tweetler $(\% 4,7)$; sorulardan oluşan tweetler $(\% 2,6)$; farklı ülkelerden aşı uygulamalarına ve politikalarına ilişkin örneklerden oluşan tweetler (\%1,9); aşı ve pandemi sürecindeki diğer tedbirlerin tutarsız olduğunu iddia eden tweetler (\%1,8); alınt yapılan ayetlerden ve sözlerden oluşan tweetler (\%1,6); aşıya ve aşı uygulamalarında yaşanan sıkıntıların çözümüne ilişkin enformasyon paylaşan tweetler $(\% 1,4)$; şifa ve baş sağlığı dileklerinden oluşan tweetler (\%1), aşıya mesafeli olan kullanıcıların aşı olanlar hakkında görüş bildirdiği tweetler $(\% 0,8)$ ve son olarak aşıya karşı mesafeli olan kullanıcıların 
ötekileştirilmekten duydukları rahatsızlığı ifade ettikleri tweetler $(\% 0,5)$ izlemektedir.

Tablo 3 ilk kategorideki itiraz ve eleştirilerin yöneldiği aktör, kurum ve uygulamalara göre tweetlerin sayısını göstermektedir.

Tablo 3. Aktörler, Kurumlar ve Uygulamaları Konu Edinen Tweetler

\begin{tabular}{|l|c|c|c|}
\hline \multicolumn{1}{|c|}{ A. Aktörler, Kurumlar ve Uygulamalar } & Tweet Sayısı & $\begin{array}{c}\text { Genel } \\
\text { Yüzde }\end{array}$ & $\begin{array}{c}\text { Kategori } \\
\text { Yüzdesi }\end{array}$ \\
\hline A1. Doktorlar & 198 & $\% 8,4$ & $\% 23,8$ \\
\hline A.2 Sağlık Bakanı & 151 & $\% 6,4$ & $\% 18,1$ \\
\hline A.3 Medya & 151 & $\% 6,4$ & $\% 18,1$ \\
\hline A.4 AK Parti & 117 & $\% 5$ & $\% 14$ \\
\hline A5. Küresel sağlık sistemi & 45 & $\% 2$ & $\% 5,4$ \\
\hline A6. Genel itiraz & 41 & $\% 1,7$ & $\% 5$ \\
\hline A7. Bilim/tıp & 37 & $\% 1,6$ & $\% 4,5$ \\
\hline A8. Sağlık örgütleri (TTB/DSÖ) & 21 & $\% 0,9$ & $\% 2,5$ \\
\hline A9. Bilim kurulu & 15 & $\% 0,7$ & $\% 1,8$ \\
\hline A10. Milli Eğitim Bakanlığı & 14 & $\% 0,6$ & $\% 1,7$ \\
\hline A11. Cumhurbaşkanı & 11 & $\% 0,5$ & $\% 1,3$ \\
\hline A 12. İ̧işleri Bakanlığı & 8 & $\% 0,4$ & $\% 1$ \\
\hline A13. Muhalefet & 7 & $\% 0,3$ & $\% 0,8$ \\
\hline A14. PCR testleri & 6 & $\% 0,3$ & $\% 0,7$ \\
\hline A15. Adalet Bakanlığı & 6 & $\% 0,3$ & $\% 0,7$ \\
\hline A16. Şirketler & 3 & $\% 0,1$ & $\% 0,4$ \\
\hline A17. TÜik & 2 & $\% 0,1$ & $\% 0,2$ \\
\hline Toplam & 833 & $\% 35,4$ & $\% 100$ \\
\hline
\end{tabular}

Aşılarla ve aşılama süreciyle ilgili en yoğun eleştiri ve itirazın $(\% 23,8)$ doktorlara yöneldiği görülmektedir. Sağıı Bakanı $(\% 18,1)$ ve medyaya $(\% 18,1)$ yönelen eleştiri ve itiraz tweetlerinin sayısı ise eşittir. Bu aktör ve kurumları sırasıyla AK Parti (\%14), küresel sağlık sistemi $(\% 5,4)$, herhangi birini veya bir kurumu hedeflemeyen genel itiraz ve eleştiri tweetleri (\%5), modern tıp ve bilimin eleştirildiği tweetler (\%4,5), Türk Tabipler Birliği ve Dünya Sağlık Örgütü gibi sağlık alanındaki örgütlerin eleştirildiği tweetler (\%2,5), Bilim Kurulu’nun (\%1,8) ve Milli Eğitim Bakanlığının $(\% 1,7)$ eleştirildiği tweetler, Cumhurbaşkanı'na yönelik itiraz ve eleştirilerden oluşan tweetler (\%1,3) ve diğerleri izlemektedir.

Tablo 4, kullanıcıların aşıların güvenilirliğinin sorgulandığı tweetlerde sunulan argümanları ve bunların sayılarını göstermektedir. 
Tablo 4. Aşı Güvenilirliği ile İlgili Tweetler

\begin{tabular}{|l|c|c|c|}
\hline \multicolumn{1}{|c|}{ B. Aşı Güvenilirliği } & Tweet Sayısı & $\begin{array}{c}\text { Genel } \\
\text { Yüzde }\end{array}$ & $\begin{array}{c}\text { Kategori } \\
\text { Yüzdesi }\end{array}$ \\
\hline B1. Komplo teorileri & 338 & $\% 14,3$ & $\% 46,7$ \\
\hline B2. Yan etki & 167 & $\% 7,1$ & $\% 23$ \\
\hline B3. Aşının koruyuculuğu & 60 & $\% 2,6$ & $\% 8,3$ \\
\hline B4. Faz çalışmaları & 46 & $\% 2$ & $\%$ 6,4 \\
\hline B5. Güvenmiyorum & 30 & $\% 1,3$ & $\% 4,1$ \\
\hline B6. Aşı içeriğindeki maddeler & 24 & $\% 1$ & $\% 3,3$ \\
\hline B7. Onam formu & 14 & $\% 0,6$ & $\% 2$ \\
\hline B8. Türkiye'deki kişi ve kurumlara güvensizlik & 9 & $\% 0,4$ & $\% 1,2$ \\
\hline B9. Doktorların görüş farklılı̆ı & 9 & $\% 0,4$ & $\% 1,2$ \\
\hline B10. Aşının ücretsiz olması & 8 & $\% 0,3$ & $\% 1,1$ \\
\hline B11. mRNA teknolojisi & 4 & $\% 0,2$ & $\% 0,6$ \\
\hline $\begin{array}{l}\text { B12. Üretici ülke ve şirketlere duyulan } \\
\text { güvensizlik }\end{array}$ & 4 & $\% 0,2$ & $\% 0,6$ \\
\hline B13. Acil kullanım onayının olmaması & 3 & $\% 0,1$ & $\% 0,4$ \\
\hline B14. Aşı üretenlerin aşı olmaması & 3 & $\% 0,1$ & $\% 0,4$ \\
\hline B15. Aşının bulunma süresinin kısa olması & 3 & $\% 0,1$ & $\% 0,4$ \\
\hline B16. Aşının varyantlara göre değişmemesi & 2 & $\% 0,1$ & $\% 0,3$ \\
\hline Toplam & 724 & $\% 30,8$ & $\% 100$ \\
\hline
\end{tabular}

Buna göre aşıların güvenilirliğini olumsuz etkileyen en önemli neden, komplo teorileridir $(\% 46,7)$. İkinci sırada ise aşıların yan etkileriyle ilgili ifadelerin yer aldığı tweetler gelmektedir (\%23). Üçüncü sırada aşıların hastalığa karşı herhangi bir koruyuculuğunun olmadığını ifade eden tweetler yer almaktadır (\%8,3). Dördüncü sırada ise aşıların faz çalışmalarının tamamlanmadığı ve bu nedenle güvenilir olmadığını ifade eden tweetler bulunmaktadır $(\% 3,9)$. Bunları sırasıyla herhangi bir neden belirtmeksizin kullanıcıların aşılara güvenmediğini belirttikleri tweetler $(\% 3,7)$, aşı içeriğinin bilinmemesi veya grafen gibi toksik maddelerin yer aldığını ifade eden tweetler $(\% 3,3)$, imzalatılan onam formundaki ifadeler nedeniyle aşının güven vermediğini ifade eden tweetler, kullanıcıların Türkiye'de sağlık alanındaki kişi ve kurumlara güvenmedikleri için aşıya güvenmediklerini ifade ettikleri tweetler, doktorlar arasında aşıyla ilgili görüş farklılıkları nedeniyle aşıya güvenmediklerini ifade ettikleri tweetler $(\% 1,2)$ ve diğerleri izlemektedir.

Twitter'da aşıyla ilgili tartışmalardan biri de getirilen kısıtlamalara ilişkindir. Bu tartışmalar İçişleri Bakanlığı tarafindan pandemi süresince yayınlanan genelgelere dayanarak aşı olmayan ve aşı sürecini tamamlamayanların okul, kampüs, 
hastane, kafe, alışveriş merkezleri, restoran gibi iç mekânlara girişine, seyahat etmesine ve çalışmasına yönelik kısıtlamaları konu almaktadır. Bu kısıtlamalara çeşitli haklar çerçevesinde itiraz eden tweetlerin dağılımı Tablo 5'te gösterilmiştir.

Tablo 5. Aşı Uygulamalarına Yönelik Hak Temelli İtirazlar

\begin{tabular}{|l|c|c|c|}
\hline \multicolumn{1}{|c|}{ C. Hak Temelli İtiraz } & Tweet Sayısı & $\begin{array}{c}\text { Genel } \\
\text { Yüzde }\end{array}$ & $\begin{array}{c}\text { Kategori } \\
\text { Yüzdesi }\end{array}$ \\
\hline C1. Anayasal hak ve özgürlükler & 10 & $\% 4,3$ & $\% 39,1$ \\
\hline C2. Eğitim hakkı & 83 & $\% 3,5$ & $\% 32,2$ \\
\hline C3. Hasta hakları & 28 & $\% 1,2$ & $\% 10,8$ \\
\hline C4. Seyahat hakkı & 27 & $\% 1,2$ & $\% 10,5$ \\
\hline C5. Çalışma hakkı & 19 & $\% 0,8$ & $\% 7,4$ \\
\hline Toplam & $\mathbf{2 5 8}$ & $\% \mathbf{1 1}$ & $\% \mathbf{1 0 0}$ \\
\hline
\end{tabular}

Tablo 5'te görüleceği üzere bu tartışmaların yaklaşık \%39'unda kısıtlamaların genel olarak anayasal hak ve özgürlüklere aykırı olduğu belirtilirken yaklaşık \%61'inde belirli hak ve özgürlükler üzerine yoğunlaşılmıştır. Buna göre kısıtlamaların eğitim hakkına aykırı olduğunu belirten tweetlerin oranı \%32, aşılama zorunluluğunun hasta haklarına aykırı olduğunu belirten tweetlerin oranı \%10,8, aşı zorunluluğunun seyahat hakkına aykırı olduğunu belirten tweetlerin oranı \%10,5 ve aşı zorunluluğunun çalışma hakkına aykırı olduğunu belirten tweetlerin oranı $\% 7,4$ 'tür.

\subsection{Betimsel Çözümleme Bulguları}

Çalışmada nicel içerik analizinde kullanılan kodlama cetvelinde yer alan kategorilerden ilk üçü betimsel çözümlemenin temalarını oluşturmaktadır. Çalışmanın amacı doğrultusunda aşı tartışmaları ve aşıya olan mesafeyle ilgili daha derin bir kavrayış geliştirebilmek için betimsel çözümleme, tartş̧maların nicel olarak yoğunlaştı̆ı "Aktörler, Kurumlar ve Uygulamalar", "Aşı Güvenilirliği” ve "Hak Temelli İtirazlar" kategorilerinin en fazla tweet sayısına sahip alt kategorilerine uygulanmıştır. Betimsel çözümleme bulguları ilgili kategori başlığı altında derlenmiştir.

\subsubsection{Aktörler, Kurumlar ve Uygulamalar}

Twitter'da aşılarla ilgili tartışmaların çok büyük bir kısmını aktörler, kurumlar ve uygulamalara yönelik eleştiri ve itirazlar oluşturmaktadır. Bu tema altında en yoğun eleştirilen grup doktorlardır. Eleştirilerin doktorlar üzerinde yoğunlaşmasının en önemli nedenlerinden biri Ege Üniversitesi Tıp Fakültesi Çocuk Sağlığı ve Hastalıkları Ana Bilim Dalı uzmanı Prof. Dr. Nuri Zafer Kurugöl'ün katıldığı NTV akşam 
haberlerinde sağlık ocaklarında zaman zaman aşıların karıştırıldığını ve küçük çocuklara yanlışlıkla kovid aşıları yapıldığını söylemesidir.

"\#Bebeklere biz anne-babalarından habersiz \#COVID19 \#aşı yapılmış bu nasıl olur derhal bunu söyleyen \#DrZaferKurugölTutuklansın ve diğer kurumlarda denetlensin benim bebeğim \#DenekDeğilBebek yeter artık bırakın yakamizi geleceğimize,bebeklerimize dokunmayın."

Allah bizi bu kotu insanlarin serrinden korusun. Bu bebekleri nasil aşilarsiniz. Rabbim senden yardim diliyoruz \#aşıhakkında

Doktorlara eleştirilerin ve itirazların yöneltildiği bir diğer konu da doktorlar ve ilaç şirketleri arasındaki ticari ilişkilerdir. Bu tartışmalarda sıklıkla öne sürülen argümanlarda doktorların büyük şirketler tarafindan maddi olarak desteklendiği iddia edilmektedir.

"Eskiden Hamile kadınlara doktorlar ağrı kesici hap ve iğne yazmaya bile çekinirlerdi. Şimdiyse küresel şebekenin mümessili $d^{*} k$ torlar deneysel sıvı iğnelerin mutlaka hamile anne adaylarına bile yapılmalı diyorlar.! \#AsıMasıOImıycam"

"Birçoğunun finansörü eli çantalı ilaç mümessilleri aracılığındaki ilaç şirketleri olan "doktorlar güruhu" içinde güvenebileceğimiz insanların sayısı bir düzineyi bulur mu bu ülkede? \#billimKurulunaGüvenmiyorum\#AsıMasıOImıycam \#AydınUEniversitesiKapılarıAc \#AsıVePcrDurdurulsun"

Tweetlerde doktorlara yöneltilen eleştirilerin ve itirazların temelini oluşturan aşı şirketleriyle ticari ilişkiler argümanı, modern tıp ve bilime, küresel sağlık sistemine ve sağlık örgütlerine yönelen eleştirilerin bazılarına da dayanak olmaktadır.

"1 Doz BioNTech aşısı 35 Euro, kişi başı 3 DozX35 Euro=105 Euro. 1 Euro 10 TL= 105 EuroX10TL= 1.050 TL 1.050 TL X 83 Milyon... Sonucu yorum yazın. İşte bu yüzden aşı olmak zorundasınız. \#SavASInMaskesiniKaldır \#AsıVePcrDurdurulsun \#Arkasokaklarboykot"

“@tgrthabertv @sevdaturkusev@drerol_kose @maranki \#aşıhakkında dünyada Sağlık bir sektör olduğu için çok büyük paralar dönüyor. Sağlık parayla olduğu için kimse bizi iglestirmez diye düşünüyorum"

"Pfizer CEO'su Albert Burla: "Çok fazla yattrım yaptık. Bilim insanlarımızı ve muhendislerimizi yeterli doz üretmek için fazla çalışmaya zorladık. Bu yüzden insanlara her yıl yeni dozlar vermek lazım" Asıl meseleyi daha nasıl itiraf etsin? BioNTech \#aşı \#AsıDeğilBiyolojikSilah"

Bazı kullanıcılar Bilim Kurulu üyelerini ve Sağlık Bakanı’nı da küresel ilaç şirketleriyle ve bu bağlamda DSÖ ile iş birliği yaptıkları iddiasıyla eleştirmektedir. 
Bu bağlamda bazı tweetlerde Türkiye'deki aşılama uygulamalarının DSÖ ve ilaç şirketlerinin dayatması sonucunda şekillendiği ve Bilim Kurulu'nda yer alan doktorlara küresel ilaç şirketleri tarafindan fon sağlandığı yönünde iddialar yer almaktadır.

"Bilim kurulu üyelerinin geçmişi, bağlantıları, araştırma sponsorları, kaynakları araştrılsın. Bebeklere gizli deney yapanlarla bağlantıları araştırılsın, buna zemin hazırlayan bilim kurulunun, bu doktorların ne olduğunu bilmek hakkımız !!! \#aşıhakkında"

"Bilim kurulu üyelerinin yabancı ilaç şirketleri ile olan bağlantıları araştırılsın. Prof. Canan Karatay ve Prof.Serhat findık hocalarımız neden bilim kurulunda değil.\#aşıhakkında"

"Film kurulu ve \#Aşı dayatmacılar .. içlerinde salgın bakanı Erol Taş varmı bilmem ama bürokratların kesinlikle bu rakamlardan çok fazla aldığı bi aşikar twitter.com/ yenisafak/stat..."

Sağlık Bakanı'na yöneltilen itirazlar sıklıkla gerçek verilerin saklandığı iddiasına dayanmaktadır. Buna göre Sağlık Bakanı, aşı nedenli ölüm vakalarının sayısını ve aşılıların yoğun bakıma yatma oranlarını saklamaktadır. Ayrıca Sağlık Bakanı aşıların yan etkisini görmezden geldiği ve buna ilişkin bilgileri sakladığı iddialarıyla da eleştirilmektedir.

"\#aşıhakkında Bakan hastanede yatanların yüzde doksanbeşi aşısı tamamlanmayanlar diyerek gerçeği algılarla oynayarak dile getirmiştir. Yani bir veya iki doz aşılılar dedi hastanede yatanlar."

“@drfahrettinkoca zararlı aşıdan sonra, şimdiden bile ölen,felç vs olan binlerce kişi var,tek kelime etmezsin. twitter vs yansıyanlar onda biri bile değil \#BioNTechYanEtki \#asımağdurları \#oeğretmen \#Corona \#pazar \#MaltepeRuhuAnıtparkta \#dolar \#PCRtestinehayır"

"Vaka haritası değil \#biontekyanetki haritası yayınla artık. \#ArkaSokaklar \#Boykot KanaID \#PCRbitersePandemiBiter \#PcrTestineHayir \#AsıMasıOlmıycam \#AsıVePcr Durdurulsun \#MaskenDuestueEsinSenol \#plandemibitiyor @RTErdogan"

Tweetlerde AK Partiye yönelen eleştiriler sıklıkla küresel şirketler ve örgütlere iş birliği yapıldığı iddialarına dayanmaktadır. Bu iddialardan bazılarının dayanağı ise DSÖ’yle 2 Mayıs 2017 tarihinde imzalanan “Türkiye Cumhuriyeti Hükûmeti ve Avrupa Bölge Ofisi Vasıtasıyla Dünya Sağlık Örgütü Arasında İnsani ve Sağlık Acil Durumlarına Hazırlıklılık DSÖ Coğrafi Ayrık Ofisinin İstanbul Türkiye'de Kurulmasına İlişkin Ev Sahibi Ülke Anlaşması"dır. Kullanıcılar bu anlaşmayla hükûmetin ülkeyi "küresel çeteye" teslim ettiğini düşünmektedir. 
"Yönetimi DSÖ'ye teslim edenler, seçimlerde hangi yüzle Milletten oy isteyecekler? \#ParisiklimAntlaşmasınahayır \#PcrDayatmasıDurdurulsun \#AsıDeğilBiyolojikSilah"

"Virüs çıkmadan 8 ay önce DSÖ'ne ülkeyi teslim etmişiz. Dsö görevlileri söyledikleri tüm sözlerden, yaptikları eylemlerden görevleri bittikten sonra bile cezadan muaflar. Geçici görevlendirilenler de. Keşke sizi oraya getiren halkınıza da bu kadar düşünseydiniz. \#asımağdurları https://t.co/Ol90sHbzhW"

"Ülke elden gidiyor, küresel çete ele geçirmiş, insan hakları yerlerde, bilim sürünüyor, hürriyet tutsak, Artik yeter Özgürlügümüzzü istiyoruz Ası pcr maske istemiyoruz \#BüyükUyanışAnkaraDa \#AsıVePcrDurdurulsun \#PcrHatalıAsıZararlı \#PCRbitersePandemiBiter"

Tweetlerde tartışmalara konu olan bir diğer aktör de medyadır. Medya sıklıkla pandemi sürecinde aşı propagandası yapmakla, "gerçek" bilim insanlarına ve doktorlara yer vermemekle, yayınladığı içeriklerde hastalıkla ilgili korku oluşturarak küresel şirketlerin aşı ticaretine yardım etmekle ve ticari çıkarları doğrultusunda gerçekleri gizlemekle eleştirilmektedir.

"\#aşıhakkında medyada hep ayni kişiler çıkıyor neden aşı karşıtı doktor çıkarmıyor medya mübalağa yaptı bu covid yüzde dört öldürücü anlayın lütfen"

"Artık hiçbir haber programı inandırıı değil. Gerçekler asla orda olmadı ama bu kadar yalan da olmamışt. \#TVyikapat bu filim bitsin. Pandemi bitsin. Korku bitsin. Ailene, akrabana, komşuna dön bir bak. Gerçekler orada \#KalpKrizleriSalgını \#BioNTechYanEtki \#asımağdurları"

"Haber spor magazin tv radyo ne kadar mecra varsa \#aşı kulisi var. Yoğun bakımlarda yer yokmuş ki zaten yoğunda hiç yeriniz olmadı.Özel hastahanelere alan açtınız. Bu kulisi cesaretiniz var ise 1 sene \#sigara ya karşı yaparmısınız eminim toplum için daha faydalı olur@mesutyar"

Tema altında yer alan tweetler incelendiğinde tartışmaların ağılıklı olarak kullanıcıların gündelik yaşamlarına devam edebilmek için aşı ve PCR testi yaptırmak istememelerinden kaynaklandığı görülmektedir. Sağlık Bakanlığı ve İçişleri Bakanlığının kamu sağlığını korumak ve vatandaşları aşıya teşvik etmek için almış olduğu tedbirlerden ortaya çıkan bu itirazlar iki ana nedene dayandırılabilir. Bunlardan ilki sağlık pazarına egemen olan küresel ilaç şirketlerine ve ilaç şirketleriyle maddi ilişki içinde olduğu düşünülen kişi ve kurumlara duyulan güvensizliktir. İkinci ana nedenin ise komplo teorileri ve yanlış bilgi olduğu görülmektedir. 


\subsubsection{Hak Temelli İtiraz}

İncelenen tweetlerde yükseltilen itirazlardan bazıları hak ve özgürlüklere vurgu yaparak diğer itirazlardan ayrışmaktadır. Bu tweetlerin çoğunda alınan tedbirlerin anayasaya aykırı olduğu ve tedbir alan kişi ve kurumların bu bağlamda suç işledikleri vurgulanmaktadır.

“@Anadolu_Univ@ProffuatErdal aşı ve pcr testi Anayasaya uygun degildir burası dsö ülkesi degil dsö nün genelgeleri bizi baglamaz aşı pcr zorunluluğu diye bir şey olamaz. \#AsıMasıOlmıycam \#PcrAsıYoekistemiyoruz \#FuatErdalEğitimHakkımaDokunma https://t.co/CZ1qOGmJUc"

“@ibbsporistanbul Anayasa ve uluslararası anlasmalar bizim haklarımızı güvence altına almışken sizin bu aldığınız karar tam olarak hangi kategoriye giriyor? \#PcrDayatmasıDurdurulsun \#PCRbitersePandemiBiter \#PCRtestinehayır \#AsıMasıOImıycam \#AsıVePcrDurdurulsun https://t.co/3dUuKd9e38"

Anayasal bir hak olmakla birlikte, kullanıcılardan bazıları itirazlarında genel hak ve özgürlüklerden ziyade daha özgül haklara odaklanmışlardır. Bunlardan ilki eğitim hakkıdır. Bazı üniversite rektörlüklerinin kovid-19 aşısı ve düzenli PCR testi yaptırmayan öğrencilerin yerleşkelere veya dersliklere girişini kısıtlaması bu itirazların temel dayanağıdır.

"\#Aşı ve pcr dayatması nedeniyle eğitim hakkının engellenmesi suçtur. Türk Ceza Kanunu 112. Maddeyi okumadınız sanırım. @EruMedya \#ÜnideEğitimHakkıEngelleniyor"

"\#ÜnideEğitimHakkıEngelleniyor Anayasanın 42.Maddesi ;"Kimse, eğitim ve öğrenim hakkından yoksun bırakılamaz. " Aşı ve PCR dayatması ile kimse bizleri şartı eğitime sürükleyemez. \#kykyurtları \#AsıMasıOlmıycam"

Tweetlerde eğitim hakkı bağlamında dikkat çeken bir diğer husus, bazı kullanıcıların alınan tedbirleri 28 Şubat süreciyle karşılaştırmasıdır. Bu bağlamda bazı kullanıcılar kovid-19'un bir halk sağlığı meselesi olduğunu göz ardı ederek başörtülü öğrencilerin üniversitelere alınmamasını aşı ve PCR yaptırmayan öğrencilerin üniversitelere alınmamasıyla aynı şekilde değerlendirmektedir.

“@Rmeysabilgir Dün başörtülü olanlar üniversitelere alınmıyordu bugün aşı olmayanlar. Nerden bakarsan bak ikisinde faşizimliktir \#YurtsuzlarGoezaltında \#salı \#AsıMasıOImıycam \#AJAvBJK \#besiktasinmacivar \#CFX"

"Neler yaşıyoruz böyle.? \#Sağığın28Şubatı mıdır nedir bu yaşadıklarımız.!? \#COVID19 \#aşı \#pcr \#ChpGelirseNeOlacak Ne olacak bunlara devam edecek! twitter. com/sukrantoray1/s..." 
Anayasal haklar bağlamında kullanıcıların itirazlarına konu olan bir diğer özgül hak, seyahat hakkıdır. Bu tweetlerde diğerlerinden farklı olarak seyahat hakkının anayasal bir hak olması vurgulanmamakla birlikte kullanıcılar, çeşitli mekânlara girebilmek ve belli hizmetlerden yararlanabilmek için HES kodu, PCR testi ve aşı istenmesinin gönüllülük söylemiyle çelişkili olduğunu ve bu nedenle aşının bir dayatma hâlini aldığını ifade etmektedir. Tartışmalarda dikkat çeken bir diğer husus kovid aşılarının bulaşı engellememesi nedeniyle kısıtlamaların ve PCR testi isteminin yalnızca aşı olmayanları kapsamasının adil olmadığına yapılan vurgudur.

"AVM, Lokanta, Kafe vb yerlere HES kodu yerine AŞI KARTI sorulacak. Oldu olacak görüldükleri yerde kurşuna dizin. Gönüllülük buysa zorunluluk nasıl olur? Insan olan sözünü tutar. \#DSÖdefol \#AsıMasıOImıycam \#KalpKrizleriSalgını \#PcrHatalıAşıZararlı \#ParisiklimAnlaşmasınaHayır"

"Hastasın taşıyıcısın ama 2 tane BioNTech aşın var. Sinemaya git, konsere git, işine git, uçağa bin, otobüse bin hiç problem değil. Ama aşısızsan ve sağlıklı olsan dahi bunların hiç birini yapamazsın. İște bilim \#Covid_19 \#Aşı \#varyant \#doğalbağışıklık \#PCRtestinehayır"

"Pembe bir çerçeve içerisinde iki marka aşı sürekli bize dayatlıyordu! Sinemaya gitmek için aşı gerekliydi, Yurt dışı seyahatleri için aşı gerekliydi.Aslında \#aşı zorunlu değildi!?! Ama mecbur bırakılmışt. Bu arada \#BioNTech hisselerine yatırım yapan zengin olmuştu! \#Sinovac https://t.co/ZnlzfFGv3M"

Hasta hakları çerçevesinde yöneltilen itirazlarda ise kullanıcılar sıklıkla kişilerin tedaviyi reddetme hakkına vurgu yapmaktadır. Bununla birlikte beden üzerinde yalnızca kişinin kendisinin söz sahibi olabileceği bazı tweetlerde hak kavramı üzerinden tartışılırken bazı tweetlerde bedenin "Allah'ın emaneti" olduğu vurgulanarak muhafazakâr anlatıdan hareket edilmektedir.

"Bu bedeni Allah bana emanet etti size değil. Bırakın da sağlığım ile ilgili şeylere ben karar vereyim. \#MaltepeRuhuAnıtparkta \#AsıMasıOImıycam"

"Insanın vücut bütünlügüne dokunulamaz. Kendi istegi olmadan kimseye müdahale edilemez."\#AsıMasıOlmıycam

“@tgrthabertv @sevdaturkusev @drerol_kose \#aşıhakkında Anayasanın 17. maddesini çiğniyorsunuz Bu beden benim aşısızlara ikinci sınıf vatandaş muamelesi yapmaktan vazgeçin, Mrna aşılarını kabul etmiyorum, Aslaaaa güvenmiyorum?”

Hasta haklarıyla ilgili tartışmalarda tweetlerden bazılarında kadınların bedenleri üzerindeki haklarına odaklanan feminist protestolarda sıklıkla kullanılan, "Benim bedenim, benim kararım" sloganına gönderme yapılmaktadır. 
Bu gönderme bazı tweetlerde yalnızca beden üzerinde kişinin kendisinin söz sahibi olacağını ifade etmek için kullanılırken bazı tweetlerde kadınların bedenleri üzerindeki haklarını savunan kişi veya kurumların aşı söz konusu olduğunda aynı desteği göstermemesinin eleştirisi olabilmektedir.

“@ttborgtr @TTBKadin Anne karnında bir bebeği jiletle kazımak serbest ama ne idüğü belirsiz bir aşıyı yaptırmamak yasak, hadi oradan! \#AsıMasıOlmıycam \#PCRbiterse PandemiBiter \#PcrDayatmasıDurdurulsun"

"Sadece kürtaj yaptrırken mi bedenlerimiz üzerinde söz sahibiyiz? @ttborgtr \#AsıVePcrDurdurulsun \#asıolmayacağım twitter.com/ttborgtr/statu..." “@ttborgtr @TTBKadin Evet bedenim bana ait ve siz dokunamazsınız \#AsıVePcrDurdurulsun"

Tweetlerde yürütülen tartışmalarda konu edilen bir diğer anayasal hak da çalışma hakkıdır. Seyahat hakkı tartş̧malarına benzer olarak bu çalışma hakkını konu edinen tartışmalarda da bir hak vurgusu yapılmamış; kullanıcıların iş yaşamlarının tedbirler ve politikalar nedeniyle uğradığı zararlara itiraz edilmiştir.

"\#AsıVePcrDurdurulsun \#asımağdurları *aşı olmak istemiyorum *Pcr testi yaptirmak istemiyorum (hiçbir semptom yok çünkü) işten atilmakta istemiyorum Napicam bilmiyorum"

"IŞ yerinden resmî yazı geldi geçen hafta ya \#Aşı yada \#Pcrtesti diye ikisinide yaptrrmadım yarın maç var kale ye destek lazım gol yemeyelim twitter.com/ secondvirus/st..."

"AŞı ve PCR testi yapmıyorum diye ihtar tutanağı ile karşı karşıyayım.Ama Rızkım ile kimse beni korkutamaz.Allah'a Tevekkül ettim. \#AsıVePcrDurdurulsun \#asıyahayır \#hakkımıhelaletmiyorum \#AsıvePcrDurdurulsun@aDilipak@asiefendisii@mucadele_plndm"

Twitter'da anayasal haklara odaklanan tartsşmalar değerlendirildiğinde kullanıcıların genel olarak itirazlarını aşı olmamaları nedeniyle ayrımcılığa maruz kaldıkları argümanına dayandırdıkları görülmektedir. Bu bağlamda ayrımcılık yaptığı düşünülen kişi ve kurumlar, eleştirilerin ve tepkilerin odağı olmaktadır. Yine bu tartışmalarda kullanıcıların kişisel hak ve özgürlüklerini başkalarının hak ve özgürlükleri ile ilişkisi içinde değerlendirmediği ve pandeminin bireysel değil, kamusal bir mesele olduğunu göz ardı ettiği söylenebilir.

\subsubsection{Aşı Güvenilirliği}

Twitter'da tartışılan bir diğer ana tema, aşının güvenilirliğidir. Kullanıcıların aşıya duydukları güveni zedeleyerek aşıya mesafeli olmalarını sağlayan en önemli ne- 
denin komplo teorileri olduğu görülmektedir. Kullanıcıların tartışmalarda sav olarak öne sürdüğü komplo teorileri ise birbirinden farklılaşmaktadır. Bu çerçevede en sık dile getirilen komplo teorilerinden biri, salgının küresel güçlerin bir oyunu olduğu ve bu küresel güçlerin aşılarla insanlara hükmetmeyi amaçladığıdır. Bununla birlikte küresel güçlerin tanımlanmasında ve aşıyla amaçlananın ne olduğu konusunda kullanıcılar birbirinden ayrışmaktadır. Çoğu kullanıcı pandeminin bir Siyonizm/Deccalizm projesi olduğunu ve amaçlanın aşılarla Müslümanların fitratını değiştirerek köleleştirmek olduğunu iddia ederken bazı kullanıcılar küresel şirketlerin kâr elde etmek için virüsü icat ettiğini ve aşıyı bir tedavi seçeneği gibi sunduğunu iddia etmektedir. Bu tweetlerde pandeminin planlı bir proje olduğunu vurgulamak için pandemiden esinlenerek türetilen "plandemi" kelimesi sıklıkla kullanılmıştır.

\footnotetext{
"\#aşıhakkında plandemi üzerinden aşılarla deccalizme geçme projesi..!"

“@sputnik_TR Hain Dünya devletleri, Siyonist katil Dso-WHO Bıll Gates Elon Musk \#Pfizer-BioNTech ve işbirlikçisi kukla, satılmış doktorlar, insanlığı AŞı bağımlısı köleler hâline getirmek için, siyonist medya'yıda yanlarına alarak saldırıyorlar.Varyantlar ve \#Aşı hiç bitirilmeyecek!"
}

"Arthk ilaç ve ası şirketlerinin hesapları dolduğuna göre plandeminin bitme vakti gelmiştir sanırım,yoksa gözünüzü toprak doyursun \#PlandemiAnkaraDaBitecek \#PcrHatalıAsıZararlı \#KalpKrizleriSalgını \#AsıVePcrDurdurulsun \#DenekDegilBebek \#AnayasaGenelgedenÜstündür"

"Doktor maaşları az olduğu için bütün doktor ve hemşireler biontek firmasından ayda 100 bin dolar alıyoruz diye Bill Gates bize beleş bilgisayar verdi diye suçlayamazsınız... Büyük oyunu çözdünüz ama para da büyük yeğen \#BirSeyYapmalı \#MansurYavas \#asımağdurları \#dgs2021"

"Ortada bir salgın yok, asi sirketleri para kazanmanın kolayını buldu . Asla asi olmiycaz \#aşıhakkında"

Pandeminin bir proje olduğunu vurgulamamakla birlikte bazı tweetlerde yine pandeminin gerçek olmadığına, bir korku politikası olduğuna yönelik inançların dile getirildiği görülmektedir.

"\#aşıhakkında Ölen insan sayısı $260 \div$ il sayısı 81 = 3.2 Yani il bazında da ölen insan sayısı 3 kişi Gerçekten ölümcül bir salgın olmuş olsa il bazında 3 kişi mi olurdu yoksa yüzlerce insan mi ölürdü"

"26 Haziran'da ilk mitingi 29 Ağustos ta ikinci mitingi yaptk maskesiz mesafesiz. 11 Eylül'de Maltepe' deki mitinge katıldık hiç birimize birşey olmadı yaşıyoruz. demem o ki salgın falan yok Salgın medyada \#aşıhakkında" 
Yine bazı tweetlerde, amacın ne olduğu belirtilmemekle birlikte, Kovid-19 virüsünün laboratuvarda üretilen yapay bir virüs olduğuna yönelik iddialar da tartışmalarda öne sürülmektedir.

"'Virüse aşı değil, Aşıya virüs bulundu." Bir sözle bu kadar güzel anlatılamazdı. \#fahrettinkocaistifa \#asıhakkında"

"Aşılılar da hasta aşısızlarda. Aşıya virüs bulundu virüse aşı bulunmadı. Kainat eczanesinden şifa aramak zorundayız artik. \#asıhakkında"

"Bizimle mücadeleye kalkışmak yerine Virüs hangi laboratuvarda yapıldı Kim sürdü? Bunlarabirkalkışmayapsaydınız?!?ArkaSokaklarAnkarada\#hakkımıhelaletmiyorum \#AsıMasıOImıycam \#plandemitiyatrosu"

Twitter'daki tartışmalarda sıklıkla öne sürülen bir diğer komplo teorisi de Kovid-19 aşılarının dünya nüfusunu azaltmak için kullanıldığıdır. Çoğunlukla Bill Gates'i hedef gösteren bu tweetlerde aşının ölümcül bir deney sıvısı olduğu vurgulanmaktadır.

"Pandemi yok aşıyla nüfus azaltılıp dünyaya hükmetmek istiyorlar \#aşıhakkında"

"Sizden bilim adamı değil iyi bir billin adamı olur ancak, gavur bills bile açık açık așı ile insanlığı azaltacağız diyebiliyorken siz gaydırı gubbak Cemile gibi kıvırtıp duruyorsunuz biraz kalıbınızın adamı olun be. \#AsıMasıOlmıycam \#AsıDeğilBiyolojikSilah twitter.com/DrMetinCakir/s... https://t.co/flcdVmIDiU"

"Deneysel sıvıya karşıyız Yeni Dünya Düzenine de karşıyız Covid19 Dünya Nüfusunun Azaltılması ve Kontrol Altına Alma Operasyonudur \#BizAşıKarşıtıDeğiliz \#ZkusağıOYUnunFarkında \#KalpKriziSalgını \#AsıVePcrDurdurulsun https://t.co/gsDaWJXXSX"

Aşının ölümcül yan etkileri olduğuna dayanarak iddia edilen bir diğer komplo teorisi de biyolojik savaştır. Bazı kullanıcılar ise bu biyolojik savaşın sadece Türkleri hedef aldığına inanmaktadır.

"Sen Türk olduğunu unutabilirsin..ama Düşman Senin Türk olduğunu ASLA unutmaz.

Bizde unutmuyoruz.. Bakan Koca \#DSOEUElkemdenDefol \#AsıMasıOlmıycam \#KoeleOlmayacağız \#PcrVeAsıyaHayır"

@sevdaturkusev@Orhan380035 Allah'ın verdiği bu canı alsalar yine yılmayacağız. Atalarımız Çanakkale'de vatanı canı pahasına savunması ile bizim \#AşıDeğilBiyolojikSilah ile mücadelemiz ve bu milleti uyandırmaya çalışmamı aynı ölçüde kutsaldır. \#Çarşamba \#BioNTechyanetki

"Türkiye bir garip ülke oldu! Virüsten ölen hiç turist olmuyor. Mülteci olmuyor Suriyeli olmuyor. Varsa yoksa TÜRK ölüyor. Virüsün kast TÜRK'e mi yoksa iki ayaklı virüslerin kastı mı TÜRK'e? Bu Hamile ve Çocuklara çok sardınız bu işin sonu iyi değil..! 


\section{\#AsıDeğilBiyolojikSilah https://t.co/z1VzYno11Q"}

Aşılarla ilgili tweetlerde öne sürülen bir başka komplo teroisi ise mRNA teknolojisine ilişkindir. Bu tweetler mRNA aşılarının insan DNA'sını ve genetik yapıyı değiştirdiği iddiasına dayanmaktadır. Bu iddialara göre mRNA aşıları insanların üreme gibi bazı temel sistemlerini bozmaktır.

"\#aşıhakkında Bakın, lütfen dikkate alın. mRna 2016 da Çinde denemeleri yapılmış, gen aktarımında kullanıldı ve bebeklere uygulandığında etik olmadığı gerekçesiyle yasaklandı. Bugün mRna nın hedefi virüs değil GELECEK. VEKTÖR VIRÜS AŞILANAMAZ. LÜTFEN, BU BILIMSEL BIR GERÇEKTIR."

@kurnali9011@Shiva_1881 Aşılılara vurulmalı, mRNA gen aşısı olan onlar Trans insan \#AşıDeğilBiyolojikSilah https://t.co/XJ3tezgUnb

@FOXhaber Iyı reklam Peki yoğun bakım ıse orda sizin ne işiniz var bu flm eski di kimse yutmuyor \#aşı diye millete kitlediginiz sıvı dan sonra doğan hamile kalan insanlar ne doğuracak merak ediyorum zalimin zulmü Eba Müslim gelmeseydi dünya ya esseklerde çağırır di Mervana mervana

\#aşıhakkında aşı hem riskli hemde tehlikeli kadınlarda emzirme sorunu çıkıcak erkeklerde kısırlık

Twitter'da aşıların güvenilirliği ile bir diğer yoğun tartışma yan etki teması üzerinden yürütülmüştür. Bu tartışmalarda, bahsedilen yan etkiler alerjiden nefes darlığına, baş ağrısından regı döngülerinde bozulmaya kadar çeşitlilik göstermekle birlikte, sıklıkla aşının yaygın olarak kalp kası iltihabına, kalp krizine ve ölüme neden olduğu belirtilmiştir. Bu bağlamda kullanıcıların birçoğunun argümanlarını yanlış bilgilere dayandırdığı söylenebilir. Nitekim çoğu tweette kaynağı belli olmayan iddialar bu yan etkilere kanıt olarak gösterilmiştir. Bazı tweetlerde ise yalnızca yan etkilere ilişkin bilgiler nedeniyle aşıya karşı duyulan çekince dile getirilmiştir. Yan etkiler hakkındaki tweetlerde dikkati çeken bir diğer nokta \#asımağdurları ve \#BioNTechYanEtki hashtaglerinin kullanıcılar tarafindan yan etkiler hakkında bilgi almak isteyenlere önerilmesidir.

"Aşı olmayanlar aşı olanlara ne olacak diye bekliyor. \#aşıhakkında"

"\#asikorur diyen doktorlara sesleniyorum. Aşı sebepli ölen hastaların otopsi sonuçları. Bunu bir doktor açıklar mı? Yoksa bu da mı yalan? \#AsıDeğilBiyolojikSilah twitter. com/DrJohnB2/statu..."

@fesraoz Veriler ortada fotoda paylaştım risk fayda analizini kişi kendi yapıp özgür iradesiyle karar vermeli. Ülkemizde şeffaf paylaşılmış bir veri yok yurt dışında durum 
vahim FDA yan etkilerden 3.dozu iptal etti. Önce \#asımağdurları \#BioNTechYanEtki taglarına bakıp öyle karar verilmeli. https://t.co/jr84A3EoMT

"Ayrıca tam doz aşılılarda kalp ve kan gibi ciddi sorunların haricinde; vücudun çeşitli yerlerinde kaşıntı eşliğinde döküntü veya/ve şiddetli diş ağrısı yaşanıyo. Sağlık sistemimiz çöktüğü için \#asımağdurları etiketiyle yan etki bildirdiğimiz bi sistemimiz var malum"

@Mimarcik3@snayir @OpDrBilgehan Tee Allahım hâla hafif atlatma diyor. Aşı olan ilk ondört gün geberecek gibioluyor, atlatirsa daha sonra başka yanetkilerle uğraşıyor. Sen hiç \#BioNTechyanetki \#asımağdurları okumadın mı?

Kullanıcıların aşıya karşı mesafeli olmalarında etkili olan bir diğer neden de aşının etkinliğine dair yanlış ve eksik bilgilerdir. Bu tweetlerde kullanıcılar aşının Kovid-19 olmayı, bulaşı ve hastalıktan ölüm ihtimalini ortadan kaldırmadığı ve kovid-19 nedeniyle ölüm oranlarındaki artışın aşılamalardan sonra düşmediği iddiasıyla aşının etkililiğini ve dolayısıyla gerekliliğini sorgulamaktadır.

"AŞı;Tedavi etmiyor AŞl; Bulaşmayı önlemiyor AŞı; Maskeyi çıkarmaya yaramıyor. AŞl; 14 günden önce hiç etki etmiyor AŞl; 2 aydan sonrada etkisi kalmıyor AŞı; 2-3 ay sonra nasıl bir yan etki olur bilinmiyor. AŞl; 3-5 sene sonra nasıl bir yan etki olur bilinmiyor. \#AsıMasıOImıycam"

"Benim anlamadığım aşılama arttkça vaka sayısı da artıyor sonra kalkıp neden aşı olmuyorsun diyorlar. Neden olayım? Bana mantiklı bir tek sebep gösterin. \#AsıMasıOlmıycam"

"iki doz BioNTech aşısı olan arkadaşım şu an pozitif ve evde karantinada. Aşı virüse karşı korumuyorsa neden aşı olayım ki? \#BoykotKanaıD \#AsıMasıOlmıycam"

Kullanıcıların aşıya duydukları güveni olumsuz yönde etkileyen bir diğer neden de aşıların faz çalışmalarını tamamlamadığı ve Türkiye'de acil kullanım onayı olmadığına yönelik yanlış bilgilerdir. Bu bağlamda aşının hâlâ deney aşamasında olduğunu iddia eden kullanıcılar tweetlerinde aşı karşıtı olmadıklarına vurgu yaparak denek olmak istemediklerini belirtmektedir. Ayrıca bu kullanıcılar faz çalışmasının tamamlanması ve ruhsatı olmaması nedeniyle "aşı" kelimesine de itiraz etmektedirler. Bu çerçevede kullanıcılar aşı yerine kullandıkları iki terimle birbirlerinden ayrışmaktadırlar: "aşı adayı" ve "deneysel sıvı"

"aşı karşıtt" değil,deneysel olan ve faz3 tamamlanmamış sıvı karşıt demek dogru olanıdır. Şimdi burada herkese soru, Karşıt tezlerin, sorgulamaların, bilimsel anlamda tartı̧̧maların ve verilerin olmadığı yerde nasıl bilimden bahsedilir. \#AsıVePcrDurdurulsun \#DenekDegilBebek twitter.com/ntv/status/144..."

"\#aşıhakkında Aşı değil faz3 aşamasındaki Aşı adayı" 
\#aşıhakkinda deneysel sıvı adi bu aşı olamaz https://t.co/qs51uc5Rrs

"Aşı karşıtt değiliz aşı adayı sıvıyı gönüllülü̈k esası diyip alttan alttan zorunlu olarak bize dayatan sistem yüzünden karşıyı. Sorgulamak veya sorgulamamak kişisel tercihtir.\#aşıhakkında"

"Kimse bu deney sıvılarının, normal aşılar gibi olduğuna beni inandıramaz. Kendinizi kandırmayın... \#asımağdurları \#AsıVePcrDurdurulsun \#PcrHatalıAsıZararlı"

Aşı içeriğine yönelik yanlış bilgiler ve aşının içeriğinin ne olduğunun bilinmemesi kullanıcıların aşıya duydukları güveni zedeleyen bir diğer neden olarak bulunmuştur. Buna göre bazı kullanıcılar aşının içinde ne olduğunu bilmediğini için aşıya güvenmediğini ifade ederken bazı kullanıcılar aşının grafen maddesi içermesi veya içeriğinin helal olmayan maddelerden oluşması nedeniyle aşıya karşı çekincelerini dile getirmiştir.

İçeriğini bilmediğim yiyeceği bile yemem sen kimsin de bana aşı zorunluluğu koyuyorsun ??? \#AsıVePcrDurdurulsun \#AnayasaGenelgedenÜstündür

"Pfizer BioNTech aşısı laboratuvarda incelenmiş. Sonuç acayip bağlantılar yapan kristal yapılar. Muhtemelen grafen.rumble.com/vl83/x-pfizer-...\#YatacakYerinizYok \#AsıVePcrDurdurulsun"

"Çocuğum gayet sağlıklı normal grip bile olmamış. Ben gidip elin gevurunun ne idüğü belirsiz aşısını yaptiricam öyle mi?Bunu bizden isteyip dayatanlarda müslüman!... biontec \#hakkımıhelaletmiyorum \#kykyurtları \#asımağdurları"

Çözümlemede aşılama sürecinde kişilere bir onam formu imzalatılması kullanıcıların aşılara duyduğu güveni zedeleyen bir diğer neden olarak karşımıza çıkmaktadır. Onam formuna bağlı olarak kullanıcıların güvenini sarsan ise oluşabilecek herhangi bir komplikasyona ilişkin tüm sorumluluğu imzaladıkları formla kendilerinin almasıdır.

\#aşıhakkında Şimdiye kadar hangi aşıda onam formu imzalatılmış söylermisiniz?

“\#AydınÜniversitesiKapılarıAç@drfahrettinkoca çıkıp oluşabilecek her türlü kötü sonuçta veya ölümde sorumluluğu üstüne alsın bizde aşı olalım hem aşıyı dayatiyorsunuzhemde kimse sorumluluk almıyor \#AsıMasıOImıycam"

"yarina garantisi olmayan bir hayat yasiyoruz kovid-19 dan belki ölmedik baska sebeble hastanede olcam neyin garantisi var ustelik imza attiriyosunuz sorumluluk almiyosaniz ben bu asiya güvenmiyorum olmuyorum olmuycam sonuna kadar \#AsıMasıOImıycam \#AsıMasıOImıycam"

Kullanıcılardan bazıları tartışamaya neden belirtmeksizin sadece aşıya güvenmediklerini belirterek katılırken yalnızca 3'ü literatürde aşı reddi tanımlamasına 
karşılık gelecek şekilde hiçbir aşıya güvenmediğini belirtmektedir. Bu noktada dikkat çeken husus hiçbir aşıya güvenmediğini ifade eden kullanıcıların tweetlerinde pandeminin gerçek olmaması, aşının biyolojik bir silah olması gibi komplo teorilerine de gönderme yapılmasıdır.

"\#aşıhakkında aşıya güvenmeyerek aşı olmak istemeyen insanları artık rahat bırakın." "Aşı sanki çok tehlikeli. \#AsıMasıOImıycam twitter.com/ufukcoskunn/st..."

"Bugüne kadar aşılara inanmadım ve inanmam. Eski yıllara baktığımızda ölüm oranları aynı. Eğer ki böyle bir salgın olmuş olsa ülke nüfusunun yüzde 10 ölmüş olmalıydı. Kalp krizleri aşıdan kaynaklı \#aşıhakkında"

"\#aşıhakkinda asla güvenmiyorum hicbir asiya saglik bakani yargilanacak gorecek bu gözler"

"Hiçbir aşı ve ilaç güvenli değil! \#AsıDeğilBiyolojikSilah \#AsıMasıOlmıycam"

Aşı güvenilirliği ile ilgili tweetlerin betimsel analizi genel olarak değerlendirildiğinde kullanıcıların aşıya karşı mesafeli olmasının ağırlıklı olarak komplo teorilerinden ve yanlış bilgilerden kaynaklandığı söylenebilir. Bu çerçevede kullanıcılar tarafindan dolaşıma sokularak yeniden üretilen yanlış bilgiler ve komplo teorileri birbirlerinden farklılaşmaktadır. Bununla birlikte çoğu kullanıcı aşı karşıtı olarak tanımlanmaya itiraz ederken çok az kullanıcının kendisini aşı karşıtı olarak konumlandırdığını söylemek mümkündür.

\section{Sonuç}

Araştırmanın birinci sorusu, Twitter'da aşıyla ilgili tartışılan konuların nicel içerik çözümlemesiyle yanıtlanmıştır. Buna göre aşı kararsızlığı yaşayan kullanıcılar en çok, aşıyla ilgili aktörler, kurumlar ve uygulamalar; aşının güvenilirliği ve alınan tedbirler nedeniyle engellendiğini düşündükleri hakları konularında tartışmışlardır. Araştırmanın diğer üç sorusunun yanıtı ise birbirleriyle ilişki içindedir. Buna göre; aşı kararsızlığı yaşayan kullanıcılar aşının güvenilirliğini en çok komplo teorileri üzerinden sorgulamıştır. Teyit.org'un (2021d) araştırma raporundan hareketle, kullanıcıların tweetlerinde sıklıkla argümanlarını komplo teorileriyle birlikte aşının kalp hastalıkları ve ölüme yol açthğı ya da ölümle sonuçlanan yan etkileri olduğu, aşının virüse karşı hiçbir koruyuculuğunun olmadığı ve aşının faz çalışmalarını tamamlamadığını iddia eden yanlış bilgilere dayandırdıkları görülmüştür. Çalışmada pandeminin küresel çete/Siyonistler tarafindan planlanan bir program olduğu, bu programın deccalizme geçmeyi veya nüfusu kontrol altına almayı planladığı gibi öne çıkan komplo teorileri "Bill Gates ve "küreselciler" merkezli anlatılar" olarak tanımlanan kategoriyle örtüşmektedir. Bununla birlikte 
çalışmada argümanlar daha çok muhafazakâr söylemden hareketle öne sürülse de bunların arasından bazı tweetlerdeki pandemi planının Türkleri hedef aldığı yönündeki argümanlarda milliyetçi bir söylem öne çıkmaktadır. Argümanların komplo teorilerine dayandığı tweetlerde pandemi, aşı, bilim kurulu ve sağlık bakanı kelimelerinin yerine kullanılan "plandemi”, aşı "deneysel sıvı", "filim kurulu”, "Bill'in kurulu" ve "salgın bakanı" gibi ifadelerle aşının ve kurumların itibarı zedelenmeye çalışılmıştır. Buna karşın yanlış bilgilerden hareket edenler ise daha çok "aşı adayı" ifadesini tercih etmiştir.

Aşı karşıtı hareketlerin güçlenmesinde ve aşı kararsızlığının artmasında; komplo teorilerinin yükselişi, hakikatin değerini yitirmesi, bireysel inanç ve düşüncelerin olguların yerini alması ve bireysel hikâyelerin önem kazanması gibi postmodernitenin imlerini görmek mümkündür. Nitekim yapılan çalışmalar var olan bilimsel bilgiye rağmen inançlardan beslenen komplo teorilerinin ve yanlış bilginin aşıların kabulü üzerindeki olumsuz etkisini ortaya koymaktadır. Benzer şekilde bu çalışmada da ticari bağlantılar ve finansal ilişkiler nedeniyle doktorlara, bilime, sağlık sistemine, sağıı örgütlerine, medyaya ve hatta bürokratlara güvenilmediği tespit edilmiştir. Ayrıca çalışmada diğer araştırmalardan farklı olarak aşılama sürecinde onam formu imzalatılmasının aşının güvenilirliğinin sorgulanmasına yol açthğı görülmüştür. Bu nedenle neoliberal politikalarla bireylere daha fazla sorumluluk atfedilmesinin ve sağlık sektörünün ticarileşmesinin sağlık alanında faaliyet gösteren kişilerin ve kurumların güvenilirliğini zedeleyerek aşılara şüpheyle yaklaşılmasını beslediği söylenebilir. Neoliberal politikalarla birlikte bireysel hikâyelerin önem kazanması, sağlığın ticarileşerek gösteriye dönüşmesi ve bireylere atfedilen birincil sorumluluk komplo teorilerini ve aşı kararsızlığını beslemektedir.

Çalışmada ayrıca gündelik hayatta sıklıkla "aşı karşıtı" olarak tanımlanan ve kovid aşısına karşı mesafeleri nedeniyle homojen bir grup olarak değerlendirilen bireylerin aşıya mesafelerinin aynı olmadığı belirlenmiştir. Tweetleri analiz edilen kullanıcıların çok azı kendisini aşı karşıtı olarak tanımlarken diğer kullanıcıların aşı kararsızlığının nedenleri birbirinden farklıdır. DSÖ’nün $(2013$, s. 1) çalışmasından hareketle; kullanıcıların aşı kararsızlığına, güven ve hâlinden memnun olma faktörlerinin etki ettiği görülmüştür. Bu nedenle infodeminin, bireylerin aşı kabulünü azaltan inançlar ya da algılarla tutumsal engellere yol açth̆̆ söylenebilir. Aşılarla ilgili internet ortamında sıklıkla dolaşan yanlış bilgi yığını, bireylerin güvenilir ve doğru bilgiye ulaşmasını engellemektedir. En fazla çevirim içi platformlarda dolaşıma giren farklı türdeki yanlış bilgi, infodemik bir sorun olarak aşı kararsızlığını besleyen bir kamu sağlığı ve güvenliği meselesi olarak görülmelidir. Sosyal medya platformları yanlış bilgiyle mücadelede bir takım denetleme mekanizmaları 
geliştirse de kullanıcılar oluşturdukları içeriklerde farklı karakterler kullanarak algoritmaları atlatmaktadır. Bu çerçevede çalışmada analiz edilen tweetlerin çoğunda "aşı" yerine "a\$̧ı", "sıvı" gibi yazım biçimlerinin tercih edildiği görülmüştür. Böylelikle Twitter'ın denetim radarından kaçan bu twetlerde yanlış bilgi yeniden üretilerek dolaşıma girmektedir. Bu nedenle, kurumsal denetim mekanizmalarının önemi yadsınmamakla birlikte, kişilerin bilgiyi doğru şekilde değerlendirebilmelerinde dijital medya okuryazarlığı becerilerinin geliştirilmesi daha etkili bir yöntemdir.

\section{Çıkar Çatışması Beyanı}

Makale yazarları herhangi bir çıkar çatışması olmadığını beyan etmiştir.

\section{Kaynakça}

Akyüz, S. S. (2021) "Aşı Karşıtlığı ve Şeffaflık Algısında Illetişim Pratikleri ve Siyasal Aidiyetlerin Rolü" Yeni Medya Elektronik Dergisi, 5 (2), 172-185

Altunışık, R., Coşkun, R., Bayraktaroğlu, S., ve Yıldırım, E. (2010). Sosyal Bilimlerde Araştırma Yöntemleri, Sakarya Yayıncılık, 5. Basım. Sakarya.

Atalay, S. (2019). Sosyolojik Bakış Açısından Aşı Karşıtlığı ve Halk Sağlığı. T. Yılmaz (Ed.), Psikoloji, Sosyoloji ve Coğrafya Bakış Açısından Sağlık içinde Ankara: Berikan Yayıncılık. ss. 61-92.

Badur, S. (2011) "Aşı Karşıtı Gruplar ve Aşılara Karşı Yapılan Haksız Suçlamalar." ANKEM Dergi, 25(Ek 2), ss. 82-86

BíLGImag (2020) 'Infodemi Virüs Kadar Hazırlıklı Olmamız Gereken Bir Güvenlik Sorunu' https://mag.bilgi.edu.tr/tr/haber/infodemi-virus-kadar-hazirlikli-olmamiz-gereken-bi/, (Erişim Tarihi: 07.03.2021)

Brennan, J. S., Simon, F. M., Howard, P. N., \& Nielsen, R. K. (2020). Types, Sources, and Claims Of Covid-19 Misinformation. Reuters Institute for the Study of Journalism. https://reutersinstitute.politics. ox.ac.uk/types-sources-and-claimscovid-19-misinformation., (Erişim Tarihi:05.03.2021)

Doğruluk Payı.com (2021a) Covid-19 Aşısıyla İlgili Söylentiler ve Komplo Teorileri, https://www.dogrulukpayi.com/bulten/covid-19-asisi-ile-ilgili-soylentiler-vekomplo-teorileri, (Erişim Tarihi:15.10.2021)

DSÖ (2013) What Influences Vaccine Acceptance: A Model of Determinants of Vaccine Hesitancy, https://www.who.int/immunization/sage/meetings/2013/april/1_ Model_analyze_driversofvaccineConfidence_22_March.pdf, (Erişim Tarihi: 07.10.2021) 
DSÖ (2017) Vaccination and Trust: How Concerns Arise and The Role of Communication in Mitigating Crises, https://www.euro.who.int/_data/assets/pdf_file/0004/ 329647/Vaccines-and-trust.PDF, (Erişim Tarihi:07.10.2021)

DSÖ (2020). Novel Coronavirus (2019-nCoV) Situation Report-13, https://www.who.int/ docs/default-source/coronaviruse/situation-reports/20200202-sitrep-13-ncov-v3.pdf, (Erişim Tarihi: 15.10.2021)

DSÖ (2021a) COVID-19 Vaccines and Vaccination. https://www.euro.who.int/en/health-topics/health-emergencies/coronavirus-covid-19/covid-19-vaccines-andvaccination, (Erişim Tarihi: 02.10.2021)

DSÖ (2021b) Vaccines and Immunization, https://www.who.int/health-topics/ vaccines-and-immunization\#tab=tab_1, (Erişim Tarihi: 29.09.2021)

Dubé, E., Ward, J. K.; Verger, P. ve MacDonald, N. E. (2021) “Vaccine Hesitancy, Acceptance, and Anti-Vaccination: Trends and Future Prospects for Public Health" Annual Review of Public Health, 42, ss.175-191

Etesaminia, S. ve Bağcı Derinpınar, K. (2021) "Aşı Tereddütlerinde Sosyal Medyanın Rolü" Uluslararası Sağlık Yönetimi ve Stratejileri Araştırma Dergisi 7(2): ss.377-390

Facebook (2021) COVID-19 ile İlgili Yanlış Bilgilere Karşı Birlikte, https://tr-tr.facebook. com/formedia/blog/together-against-covid-19-misinformation-a-newcampaign-in-partnership-with-the-who, (Erişim Tarihi: 17.10.2021)

Fisk, R. J. (2021) "Barriers to Vaccination for Coronavirus Disease 2019 (COVID-19) Control: Experience from the United States." Global Health Journal, 5, ss. 51-55

Gölbaşı S. D., Metintaş S. COVID-19 Pandemisi ve İnfodemi. ESTÜDAM Halk Sağlığı Dergisi. 2020;5(COVID-19 Özel Sayısı):126-37.

Kader, Ç. (2019) “Aşı Karşıtlığı: Aşı Karasızlığı ve Aşı Reddi.. ESTÜDAM Halk Sağlığı Dergisi. $4(3)$, ss. $377-88$

Macdonald, N. E. ve Dubé, E. (2020). Promoting Immunization Resiliency in The Digital Information Age. Can Commun Dis Rep, 46, 20-24.

Özceylan, E.; Toprak, D. ve Esen E. S. (2020) "Vaccine Rejection and Hesitation in Turkey". Human Vaccines and Immunotherapeutics, 16(5), ss.1034-1039

PAHO (2021). Understanding The Infodemic And Misinformation in The Fight Against Covid-19, https://iris.paho.org/bitstream/handle/10665.2/52052/Factsheet-infodemic_eng.pdf?sequence $=14$ \&isAllowed $=y$, (Erişim Tarihi: 22.02.2021)

Stemler, S. (2000). "An Overview of Content Analysis", Practical Assessment, Research and Evaluation, 7/7, s. 1-7

Teyit.org (2021a) https://teyit.org/analiz-guncel-onam-formunun-covid-19-asisinin-fazcalismalarinin-bitmedigini-gosterdigi-iddiasi, (Erişim Tarihi: 15.10.2021)

Teyit.org (2021b) https://teyit.org/analiz-pfizer-bioNTech-asisinin-yan-etkisinin-olumoldugu-iddiasi, (Erişim Tarihi: 15.10.2021) 
Teyit.org (2021c) https://teyit.org/analiz-pfizer-BioNTech-covid-19-asisinin-yuzde-99grafen-oksit-icerdigi-iddiasi, (Erişim Tarihi:15.10.2021)

Teyit.org (2021d) "Türkiye'de Aşı Dezenformasyonu: Yanlış Bilgiyi Kimler Yayıyor, İlişki Ağları Ne?" https://teyit.org/teyitpedia-turkiyede-asi-dezenformasyonu-yanlisbilgiyi-kimler-yayiyor-iliski-aglari-ne, (Erişim Tarihi: 18.10.2011)

Twitter (2021) Bağlantıları Engellemeye Yönelik Yaklaşımımız, https://help.twitter.com/tr/ safety-and-security/phishing-spam-and-malware-links, Erişim Tarihi: 20.10.2011

Ünver, H. A. (2020) "Türkiye'de Doğruluk Kontrolü ve Doğrulama Kuruluşları" EDAM Siber Politikalar ve Dijital Demokrasi, https://edam.org.tr/wp-content uploads/2020/06/T\%C3\%BCrkiyede-Do\%C4\%9Fruluk-Kontrol\%C3\% BC-ve-Do\%C4\%9Frulama-Kurulu\%C5\%9Flar\%C4\%B1-Ak\%C4\%B1n-\%C3 \%9Cnver.pdf, (Erişim Tarihi: 07.10.20211)

White, M. D. ve Marsh, E. E. (2006). “Content Analysis: A Flexible Methodology”, Library Trends, 55/1, s. 22-45.

Wolcott, H. F. (1994). Transforming Qualitative Data: Description, Analysis, and Interpretation. Sage.

Yıldırım, A. (2020) “Dijital Çağda Dijital Pandemi: Türkiye'de Covid-19 Gündemi” Intermedia Internatonal e-Journal, 7(3): ss 381-401

Yıldız, Z.; Gencer, E. ve Gezegen, N. F. (2021) “Covid-19 Pandemi Sürecinde Geliştirilen Aşılara Karşı Bireylerin Tutumlarının Değerlendirilmesi Üzerine Uygulamalı Bir Çalışma" Gümüşhane Üniversitesi Sosyal Bilimler Enstitüsü Elektronik Dergisi, 12(3), 877-889.

YouTube (2021) YouTube, Yanlış Bilgilendirmelerle Nasıl Mücadele Ediyor? https://www. youtube.com/intl/ALL_tr/howyoutubeworks/our-commitments/fighting-misinformation/, (Erişim Tarihi: 19.10.2011) 


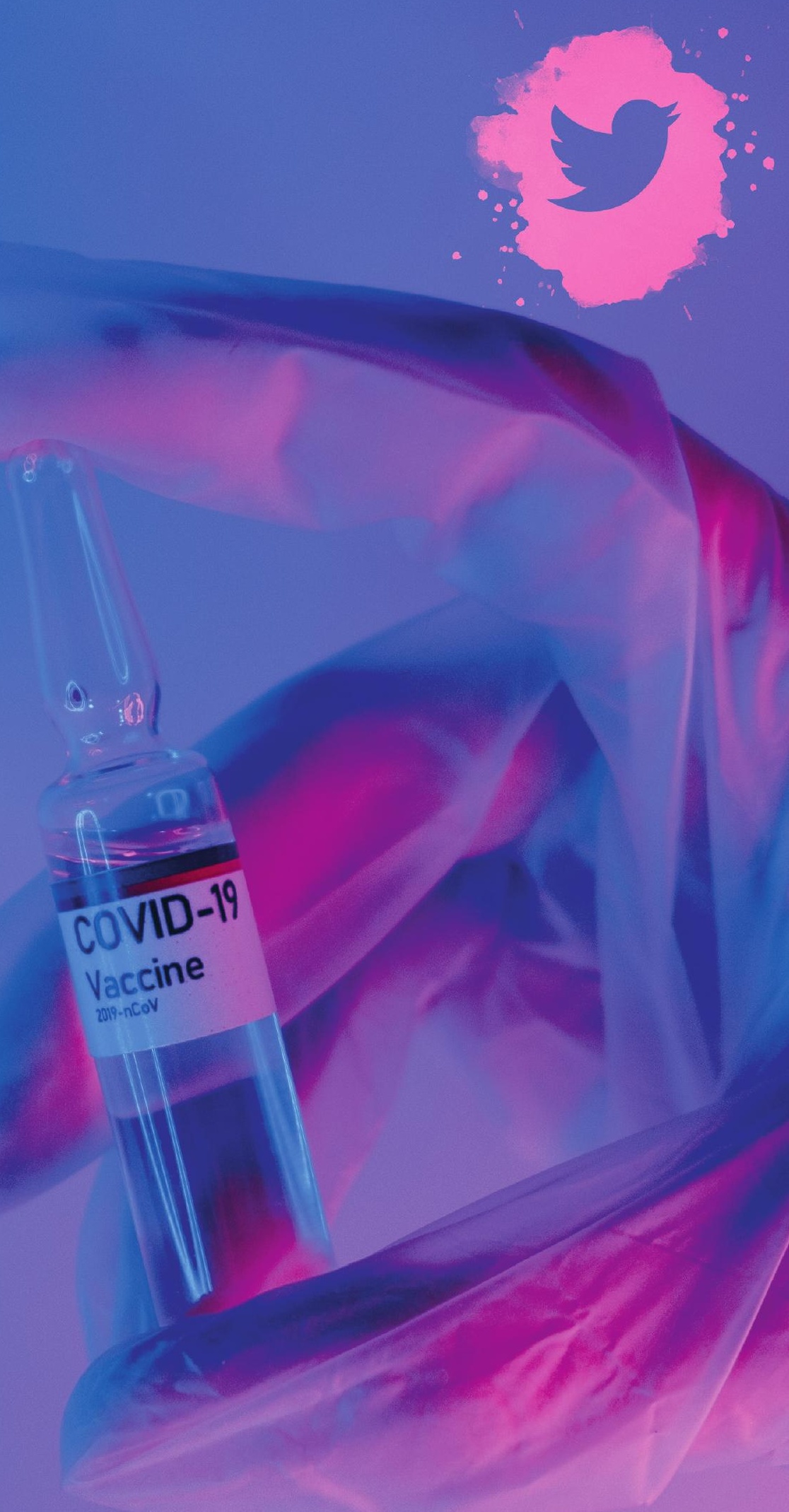

Pexels 